\title{
Bond strength to dentin of low-shrinkage composite resin restorations after thermocycling and mechanical loading
}

\section{Resistência de união à dentina com restaurações de resina composta de baixa contração} após termociclagem e ciclagem mecânica

Resistencia de unión a la dentina de restauraciones de composite de baja contracción después del ciclo térmico y la carga mecánica

\author{
Erika Kiyoko CHIBA ${ }^{\mathbf{1}}$ \\ André Luiz Fraga BRISO ${ }^{2}$ \\ Rodrigo Sversut de ALEXANDRE ${ }^{3}$ \\ Mariana Dias MODA ${ }^{2}$ \\ Paulo Henrique dos SANTOS ${ }^{4}$ \\ Ticiane Cestari FAGUNDES ${ }^{2}$
}

\author{
${ }^{1}$ Department of Pediatric Dentistry and Public Health, Araçatuba School of Dentistry, São Paulo State University (UNESP), 16015-050 Araçatuba, SP, Brazil \\ ${ }^{2}$ Department of Restorative Dentistry, Araçatuba School of Dentistry, São Paulo State University (UNESP), 16015-050 Araçatuba, SP, Brazil \\ ${ }^{3}$ Department of Dental Materials, University Center Northern of São Paulo (UNORP), 15020-040 São José do Rio Preto, SP, Brazil \\ ${ }^{4}$ Department of Dental Materials and Prosthodontics, Araçatuba School of Dentistry, São Paulo State University (UNESP), 16015-050 Araçatuba, SP, Brazil
}

\begin{abstract}
Objective: This study evaluated the in vitro bond strength of Class I restorations to dentin, using four restorative systems. Materials and Methods: Ninety-six molars were used, and a Class I cavity was prepared on the occlusal surface. Next, tooth were divided into 4 groups $(\mathrm{n}=24)$, Single Bond Universal + Filtek Z350 XT (SFZ); Single Bond Universal + Filtek Bulk Fill (SFB); AdheSE + Tetric N-Ceram (ATC) and AdheSE + Tetric N-Ceram Bulk Fill (ATB).Thus, the teeth were divided into 3 subgroups $(\mathrm{n}=8)$ : 1$)$ storage in water for 24h (control); 2) submitted to thermocycling; 3) mechanical loading. After challenges, teeth were cut into beams $0.8 \mathrm{~mm}^{2}$, being 3 to 4 sticks per tooth. Then, the specimens were submitted to microtensile testing ( $\mu$ TBS). The data were submitted to Kruskal Wallis and Dunn tests for multiple comparisons, with a significance level of 5\%. Results: No significant differences were observed between the restorative systems after thermal cycling challenge ( $p>0.05)$. However, the SFZ group presented the highest $\mu$ TBS values, with a statistical difference when compared to the ATC, SFB and ATB groups after mechanical loading ( $>$ > 0.05). Conclusion: The dentin bond strength of low-shrinkage composite resin restorations was negatively influenced by mechanical loading in class I cavities.
\end{abstract}

Descriptors: Dental Materials; Permanent Teeth; Resin Composite; Restoration; Substrate Cycling.

Resumo

Objetivo: Este estudo avaliou a resistência de união de restaurações Classe I em dentina in vitro, utilizando quatro sistemas restauradores. Materiais e Métodos: Noventa e seis molares foram usados e uma cavidade Classe I foi preparada na superfície oclusal. Na sequência, os dentes foram divididos em 4 grupos $(\mathrm{n}=24)$ : Single Bond Universal + Filtek Z350 XT (SFZ); Single Bond Universal + Filtek Bulk Fill (SFB); AdheSE + Tetric N-Ceram (ATC) and AdheSE + Tetric N-Ceram Bulk Fill (ATB). Após as restaurações, os dentes foram subvididos em 3 grupos (n=8): 1) estocagem em água por 24h; 2) submetidos à termociclagem; 3) ciclagem mecânica. Após os desafios, os dentes foram cortados em palitos com $0,8 \mathrm{~mm}^{2}$, sendo 3 a 4 palitos por dente. Então, os espécimes foram submetidos ao teste de microtração ( $\mu$ TBS). Os dados foram submetidos aos testes de Kruskal Wallis e Dunn para múltiplas comparações, com nível de significância de 5\%. Resultados: não houve diferenças significativas entre os sistemas restauradores após o desafio de termociclagem ( $>$ 0,05 ). Entrentato, o grupo SFZ apresentou os mais altos valores de resistência de união, com diferença estatística comparado aos demais grupos, após a ciclagem mecânica ( $p<0,05)$. Conclusão: a união entre dentina e as resinas de baixa contração foi negativamente afetada pela ciclagem mecânica em cavidades classe I.

Descritores: Materiais Dentários; Dentes Permanentes; Resina Composta; Restauração; Ciclagem De Substrato.

\section{Resumen}

Objetivo: Este estudio evaluó la fuerza de unión de las restauraciones de Clase I en dentina in vitro, utilizando cuatro sistemas restauradores. Materiales y métodos: se utilizaron noventa y seis molares y se preparó una cavidad de clase I en la superficie oclusal. Luego, los dientes se dividieron en 4 grupos $(\mathrm{n}=24)$ : Single Bond Universal + Filtek Z350 XT (SFZ); Single Bond Universal + Filtek Bulk Fill (SFB); AdheSE + Tetric N-Ceram (ATC) y AdheSE + Tetric N-Ceram Bulk Fill (ATB). Después de las restauraciones, los dientes se sometieron a 3 grupos (n = 8): 1) almacenamiento en agua durante 24 horas; 2) sometido a termociclado; 3) ciclismo mecánico. Después de los desafíos, los dientes se cortaron en palillos de $0,8 \mathrm{~mm}^{2}$, de 3 a 4 palillos por diente. Luego, las muestras se sometieron a la prueba microtensil ( $\mu$ TBS). Los datos se enviaron a las pruebas de Kruskal Wallis y Dunn para comparaciones múltiples, con un nivel de significancia del 5\%. Resultados: no hubo diferencias significativas entre los sistemas restauradores después del desafío de termociclado (p> 0.05). Sin embargo, el grupo SFZ mostró los valores de fuerza de unión más altos, con una diferencia estadística en comparación con los otros grupos, después del ciclo mecánico (p $<0.05$ ). Conclusión: la unión entre la dentina y las resinas de baja contracción se vio afectada negativamente por el ciclo mecánico en las cavidades de clase I.

Descriptores: Materiales Dentales; Dientes Permanentes; Resina Compuesta; Restauración; Ciclos De Sustrato.

\section{INTRODUCTION}

The goal of improving restorative material technology has been to improve tooth-restorative material bonding durability and protecting the integrity of the dental structure ${ }^{1}$. The self-etching adhesive was one evolution, simplifying the clinical steps and providing a low sensitivity technique a new adhesive system, referred to as a Universal bonding agent, has been commercialized in a single bottle and can be used in self-etch or total-etch procedures ${ }^{1}$.

The other modification to the restorative technique and composite technology is related to the advent of a bulk fill composite resin ${ }^{2-4}$. This new composite resin category contains high molecular weight monomers - urethane dimethacrylate (UDMA), bisphenol $\mathrm{A}$ and polyethylene glycol diether diethacrylate (Bis-EMA), added to inorganic particles such as: silica, zirconia, non-aggregated / non-agglomerated ytterbium trifluoride, and/or titanium dioxide ${ }^{3}$. In general, these composites have reduced filler content due to the size of their particles and, therefore, a low modulus of elasticity, which gives the material greater fluidity ${ }^{3}$. Some monomers 
are characterized by their plasticity, related to lower contraction stress $^{3}$, allowing the insertion of a single increment of up to $4 \mathrm{~mm}$ in thickness $\mathrm{s}^{2-4}$.

Restorative materials are constantly exposed to different degrading agents in the oral environment. There are in vitro methods used to simulate bond degradation that describes important points related to the clinical performance of restorations, including thermocycling and mechanical loading ${ }^{5}$. Thermal variation in the oral environment induces deterioration between a tooth substrate and a restorative material by generating expansion/contraction stress ${ }^{6,7}$. Another mode of degradation can be produce by occlusal loading6, as mechanical loading induces some micro cracks at the restoration interface and reducing the long-term survival rate of bonding ${ }^{6}$.

The literature is scarce with regards to studies that have examined the influence of thermocycling and mechanical loading on the bond strength of different low-shrinkage composite resin systems for Class I restorations when compared to traditional composite used incrementally. Thus, the objective of this study was to evaluate the in vitro dentin bond strength of four restorative systems, after thermal and mechanical load cycling. The objective of this present study was achieved, since it was possible to subject the com to the microtensile bond strength after the proposed challenges. The first null hypothesis was that there is no difference between restorative systems in the same experimental condition. The second null hypothesis was that there is no difference between different storages when the same restorative system was analyzed.

\section{MATERIAL AND METHOD}

\section{- Sample preparation}

Ninety-six extracted human permanent molar teeth were cleaned using a slurry pumice with a brush and low-speed handpiece. The teeth used in this study were properly donated by private clinics through the use of a signed informed consent form and approval of the local Ethics Committee (\#56540716. $0.0000 .5420)$. Class I cavities were prepared on the occlusal surface of each tooth using cylindrical diamond burs in a high speed handpiece and air-water spray (2094 KG Sorensen, São Paulo, SP, Brazil). The diamond burs were changed after 5 cavity preparations. Cavity measurements were checked $(7 \mathrm{~mm} \times 6 \mathrm{~mm} \times 4 \mathrm{~mm})$ using a calibrated probe.

\section{- Experimental groups}

Teeth were divided into four equal groups using a random table number $(\mathrm{n}=24)$, according to each restorative system: Single Bond Universal + Filtek Z350 XT (SFZ, 3M Espe, St Paul, MN, USA) and AdheSE + Tetric N-Ceram (ATC, Ivoclar Vivadent Schaan, Liechtenstein), both considered as control groups; Single Bond Universal + Filtek Bulk
Fill (SFB, 3M/ESPE) and AdheSE + Tetric N-Ceram Bulk Fill (ATB, Ivoclar Vivadent) were considered test groups. The groups were subsequently subdivided into 3 subgroups $(\mathrm{n}=8)$ : control (storage $24 \mathrm{~h}$ in water), thermocycling, and mechanical loading. The sample size is in accordance with Armstrong et al. ${ }^{8}$.

\section{- Restorative Procedure}

The composition and manufacturers' information of these materials are presented in (Table 1). The restorative systems were applied according to the manufacturers' instructions. All cavities received selective enamel conditioning using $37 \%$ phosphoric acid gel for $30 \mathrm{~s}$. Next, the teeth were washed with water for over $60 \mathrm{~s}$ and dried with a gentle stream of air. All materials were light cured using the curing unit LED (VALO, Ultradent Products Inc., South Jordan, UT, USA), $1000 \mathrm{~mW} / \mathrm{cm} 2$ in the standard mode for $20 \mathrm{~s}$. All samples were immersed in $10 \mathrm{~mL}$ of distilled water and were stored at $37^{\circ} \mathrm{C}$ for $24 \mathrm{~h}$.

Table 1. Composition and application steps of the materials according to the manufacturer's instructions

\begin{tabular}{|c|c|c|c|}
\hline $\begin{array}{c}\text { Material/ } \\
\text { Batch } \\
\text { Number }\end{array}$ & Manufacturers & Compositions & $\begin{array}{l}\text { Modes of } \\
\text { application }\end{array}$ \\
\hline $\begin{array}{c}\text { Single Bond } \\
\text { Universal } \\
595105\end{array}$ & $\begin{array}{l}\text { 3M ESPE, } \\
\text { St Paul, MN, USA }\end{array}$ & $\begin{array}{l}\text { MDP Phosphate monomer, } \\
\text { Dimethacrylate resins, Vitrebond }{ }^{\mathrm{TM}} \\
\text { Copolymer, Filler, Ethanol, Water, } \\
\text { Initiators, Silane }\end{array}$ & $\begin{array}{l}\text { Apply for } 20 \mathrm{~s} \text {; } \\
\text { apply a stream of } \\
\text { air for about } 5 \mathrm{~s} \\
\text { until the solvent } \\
\text { has evaporated } \\
\text { completely; light- } \\
\text { cure for } 10 \mathrm{~s} \text {. } \\
\left(1000 \mathrm{~mW} / \mathrm{cm}^{2}\right)\end{array}$ \\
\hline $\begin{array}{l}\text { AdheSE } \\
\text { T41025 } \\
\text { T45457 }\end{array}$ & $\begin{array}{l}\text { Ivoclar Vivadent, } \\
\text { Schaan } \\
\text { Liechtenstein }\end{array}$ & $\begin{array}{l}\text { Primer: Phosphonic acid acrylate, } \\
\text { Bis-acrylamide, Water, Initiators } \\
\text { and stabilizers } \\
\text { Bond: } \\
\text { Hydroxyethyl methacrylate, Highly } \\
\text { dispersed silicon dioxide, Initiators } \\
\text { and stabilizers }\end{array}$ & $\begin{array}{l}\text { Apply Primer for } \\
15 \mathrm{~s} ; \text { apply a stream } \\
\text { of air for about } 5 \mathrm{~s} \\
\text { until no visible } \\
\text { film; apply Bond } \\
\text { beginning at the } \\
\text { dentin; light-cure } \\
\text { for } 10 \mathrm{~s} \text {. } \\
\left(1000 \mathrm{~mW} / \mathrm{cm}^{2}\right)\end{array}$ \\
\hline $\begin{array}{l}\text { Filtek Z350 } \\
\text { XT (SFZ) } \\
\text { color A2B } \\
\\
342263 \\
507490\end{array}$ & $\begin{array}{l}\text { 3M ESPE, } \\
\text { St Paul, MN, USA }\end{array}$ & $\begin{array}{l}\text { Bis-GMA, UDMA, TEGDMA and } \\
\text { bis-EMA; non agglomerated/non- } \\
\text { aggregated silica filler }(20 n m) \text {, non- } \\
\text { agglomerated/non-aggregated } \\
\text { zirconia filler }(4 \text { to } 11 \mathrm{~nm}) \text {, and } \\
\text { aggregated zirconia/silica cluster } \\
\text { filler (comprised of } 20 \mathrm{~nm} \text { silica and } \\
4 \text { to } 11 \mathrm{~nm} \text { zirconia particles). } \\
\text { Fillers: } 78.5 \% \text { by vol and } 63.3 \% \text { by } \\
\text { weight. }\end{array}$ & $\begin{array}{l}\text { Individual } \\
\text { increments using } \\
\text { an incremental } \\
\text { technique. Each } \\
\text { increment was } \\
\text { polymerized for 20s } \\
\text { and the last one for } \\
\text { 40. } \\
\left(1000 \mathrm{~mW} / \mathrm{cm}^{2}\right)\end{array}$ \\
\hline $\begin{array}{c}\text { Filtek Bulk } \\
\text { Fill (SFB) } \\
\text { color A2 } \\
\\
\text { N685666 } \\
\text { N693019 }\end{array}$ & $\begin{array}{l}\text { (3M ESPE, St Paul, } \\
\text { MN, USA) }\end{array}$ & $\begin{array}{l}\text { AUDMA, Dimetacrylate AFM, } \\
\text { UDMA, DDMA; non- } \\
\text { agglomerated/non-agregated silica } \\
\text { filler (20nm), a non- } \\
\text { agglomerated/non-aggregated } \\
\text { zirconia filler ( } 4 \text { to } 11 \mathrm{~nm} \text { ), an } \\
\text { aggregated zirconia/silica cluster } \\
\text { filler (comprised of } 20 \mathrm{~nm} \text { silica } \\
\text { and } 4 \text { to } 11 \mathrm{~nm} \text { zirconia particles), } \\
\text { agglomerate Ytterbium trifluoride } \\
\text { (100 nm). Fillers: } 76.5 \% \text { by vol and } \\
58.4 \% \text { by weight. }\end{array}$ & $\begin{array}{l}\text { One incremental- } \\
\text { fill of } 4 \mathrm{~mm} \text { using a } \\
\text { bulk technique. The } \\
\text { increment was } \\
\text { polymerized for } \\
20 \text {. (100omW } \\
\left./ \mathrm{cm}^{2}\right)\end{array}$ \\
\hline $\begin{array}{l}\text { Tetric N- } \\
\text { Ceram (ATC) } \\
\text { color A2 } \\
\text { U43332 }\end{array}$ & $\begin{array}{l}\text { (Ivoclar Vivadent, } \\
\text { Schaan } \\
\text { Liechtenstein) }\end{array}$ & $\begin{array}{l}\text { UDMA, Bis-GMA, Bis-EMA, } \\
\text { triethyleneglycol dimethacrylate; } \\
\text { barium glass, ytterbium trifluoride, } \\
\text { mixed oxide, silicon dioxide, } \\
\text { copolymers, additives, stabilizers, } \\
\text { catalysts, pigments. Fillers: } 80-81 \% \\
\text { by vol and } 55-57 \% \text { by weight. }\end{array}$ & $\begin{array}{l}\text { Individual } \\
\text { increments using } \\
\text { an incremental } \\
\text { technique with } 2 \\
\text { mm or } 1.5 \mathrm{~mm} \\
\text { increments } \\
\text { adaptation to the } \\
\text { cavity walls. Each } \\
\text { increment light } \\
\text { cured for 10s. } \\
\left(1000 \mathrm{~mW} / \mathrm{cm}^{2}\right)\end{array}$ \\
\hline $\begin{array}{l}\text { Tetric N- } \\
\text { Ceram Bulk } \\
\text { Fill (ATB) } \\
\text { color IVA } \\
\text { Uo3o89 }\end{array}$ & $\begin{array}{l}\text { (Ivoclar Vivadent, } \\
\text { Schaan } \\
\text { Liechtenstein) }\end{array}$ & $\begin{array}{l}\text { BisGMA, UDMA, BisEMA; barium } \\
\text { glass, ytterbium trifluoride, mixed } \\
\text { oxide, prepolymers. Fillers: } 75-77 \% \\
\text { by vol and } 53-55 \% \text { by weight. }\end{array}$ & $\begin{array}{l}\text { One incremental fill } \\
\text { of } 4 \mathrm{~mm} \text { using a } \\
\text { bulk technique. The } \\
\text { increment was } \\
\text { polymerized for } \\
10 \text { s. }\left(1000 \mathrm{~mW} /^{2}\right) \\
\left.\mathrm{cm}^{2}\right) \text {. }\end{array}$ \\
\hline
\end{tabular}

Bis-GMA: bisphenol A diglycidyl methacrylate; Bis-EMA: bisphenol A diglycidyl methacrylate ethoxylated; TEGDMA: triethylene glycol dimethacrylate; UDMA: urethane dimethacrylate; MDP: 10-methacryloxydecyl dihydrogen phosphate, AFM: addition-fragmentation monomers; DDMA: Dodecanediol dimethacrylate; vol: volume 


\section{- Thermocycling and mechanical loading}

The samples were subjected to thermal cycling using a thermal cycling machine (Model 521 -E Ethics Equipment Scientific, São Paulo, SP, Brazil). The cycling consisted of 10,000 cycles of 30 $\mathrm{s}$ each, with an interval of $3 \mathrm{~s}$ in temperatures of $5^{\circ} \mathrm{C}$ and $55^{\circ} \mathrm{C}$. The number of cycles completed was 100,000 , corresponding to 12 months of simulated clinical aging'. For mechanical loading, each root was immersed in wax for $2 \mathrm{~s}$ up to $3 \mathrm{~mm}$ below the coronal portion of the root, which created an approximately $0.3 \mathrm{~mm}$ thick wax layer. The thickness of the wax layer was confirmed using a digital caliper before and after immersion. All roots were then embedded in PVC cylinders (height: $14 \mathrm{~mm}$; diameter: $25 \mathrm{~mm}$ ). The most coronal $3 \mathrm{~mm}$ section of the root was exposed to simulate the bone limit 2.0 $\mathrm{mm}$ above the cemento-enamel junction. Self-curing acrylic resin (Dencrilay, Dencril, Caieiras, SP, Brazil) was mixed at a 3:1 (powder:liquid) ratio and poured into the PVC cylinder. After resin polymerization, the teeth were covered by wax were separated from the cylinders, and the wax was removed from the root surface and the acrylic resin interior using hot water and manual instruments. A periodontal ligament was simulated by using silicone (Futura AD dense; DFL Ind. e Com. S.A, Rio de Janeiro, RJ, Brazil) along the artificial alveolus created in the acrylic resin ${ }^{10}$. The teeth were then subjected to load cycling (MSFMELQUIP, Equipment for the Dentistry Research, São Carlos, SP, Brazil) using an $80 \mathrm{~N}$ force with a frequency of $1.0 \mathrm{~Hz}$ applied for 50,000 cycles and standardized using a calibration unit (MS 50, Líder Balanças, Araçatuba, SP, Brazil) ${ }^{11,12}$.

\section{- Microtensile bond strength ( $\mu T B S)$}

After $24 \mathrm{~h}$ of restorations for control groups or immediately after challenges for other groups, the roots of each sample were sectioned $2 \mathrm{~mm}$ below the cement-enamel junction and sectioned into beams with a cross-sectional bonded area of approximately $0.8 \mathrm{~mm}^{2}$ using a diamond saw (ISOMET 1000; Buehler, Illinois, USA) ${ }^{13}$. Three or four beams were used from each restored tooth, and the average value for each tooth was calculated ${ }^{8}$.

Beams were fixed to a universal testing machine (OM 100 - Odeme Dental Research, Luzerna, SC, Brazil) using a cyanoacrylate adhesive (Loctite Super Bonder Gel; Henkel, Düsseldorf, Germany) and tested in tension at a crosshead speed of $0.7 \mathrm{~mm} / \mathrm{min}$ until fracture. Maximum tensile load was divided by specimen cross-sectional area to express results in units of stress (MPa). The premature failure specimens were discarded and described.

\section{- Failure modes Analysis}

Failure modes were determined by examining the fractured specimens with stereoscopy and were classified as: cohesive-dentin (failure in dentin), adhesive (failure in adhesive interface), cohesiveresin (failure in resin), or mixed (adhesive and cohesive failure simultaneously). Representative failures were selected and examined using a scanning electron microscope (SEM) (LEO 435 VP; LEO Electron Microscopy Ltd, Cambridge, UK). Specimens were mounted on aluminum stubs and gold-sputter coated (SCD 050, Balzers, Liechtenstein) prior to viewing at $1500 \mathrm{x}$ magnification.

\section{- Statistical Analysis}

All data were tested for normality (Kolmogorov-Smir-nov with Lilliefors' correction) and equal variances (Lev-ene medial test). We did not find normality assured by the two tests applied and did not find homogeneity of the variances for Challenge. However, as guaranteed by the Central Limit Theorem, we can use parametric tests when the sampling is superior to 30 cases, which in this work is extremely superior. In addition, the data are quantitative and very continuous, where the mean and variance analysis (ANOVA test) is more powerful than a nonparametric analysis (which analyzes the position of the data). In this way, as we have 2 main factors that are Resin (with 4 levels) and Challenge (with 3 levels), we decided to use GLM (General Linear Models) model that will test the effect (statistical significance) of these main factors and their interaction in the Mpa mean result, with a significance level of 5\%. Pretest failures were not included in the statistical analysis.

RESULTS

Data from $\mu$ TBS are presented in (Table 2). All control and thermocycled groups presented statistically similar results $(\mathrm{p}>0.05)$. Mechanical loading decreased the $\mu$ TBS for all restorative systems ( $p$ <.05), with the exception of SFZ. Furthermore, ATC, SFB and ATB had statistically significant similar bond strength reduction when comparing the control and thermocycling conditions to mechanical loading.

The failure modes and their classification are presented in (Table 3). The predominant failure was adhesive (Figure 1A and 1B), except for SFZ and SFB in the control groups, which presented a higher percentage of mixed failures (Figure 1C and 1D). When comparing the restorative systems for adhesive failures, the conventional systems did not present statistical differences for the control and thermocycling conditions when compared to the bulk systems ( $p>0.05)$. For mechanical cycling condition, a statistical difference was observed when the SFZ and SFB subgroups were compared $(\mathrm{p}<0.05)$. With regards to the mixed type fracture, the control subgroup SFZ obtained statistically different percentage values when compared to the SFB subgroup in the same condition ( $\mathrm{p}<0.05)$. There was 
no statistical difference between restorative systems for cohesive failures ( $>$ > 0.05). When analyzing the subgroups of the same restorative system, the SFZ thermocycled group obtained a statistically different percentage of failures when compared to the other conditions ( $\mathrm{p}<0.05$ ); as additionally, the SFB control subgroup presented a difference for the other conditions evaluated ( $\mathrm{p}<0.05$ ). Regarding mixed failures, the SFZ and SFB control subgroups obtained higher percentage values, which were statistically different to the other subgroups $(\mathrm{p}<0.05)$. Representative SEM images are presented in Figure 1.

Table 2. Mean values and standard deviation of bond strength (MPa), minimum, maximum, median, standard deviation and number of beams tested per group

\begin{tabular}{|c|c|c|c|c|c|c|c|c|}
\hline Groups & Challenge & Mean & & Min & Max & Median & SD & $\mathbf{N}$ \\
\hline \multirow{3}{*}{ SFZ } & $\mathrm{C}$ & 17.94 & A & 1.01 & 51.07 & 14.30 & (12.19) & 29 \\
\hline & $\mathrm{T}$ & 15.65 & A & 2.13 & 39.25 & 12.41 & 9.67) & 31 \\
\hline & M & 14.04 & A & 0.55 & 43.67 & 14.90 & $(11.17)$ & 24 \\
\hline \multirow{3}{*}{ SFB } & $\mathrm{C}$ & 17.49 & A & 2.02 & 43.85 & 17.49 & $(10.22)$ & 29 \\
\hline & $\mathrm{T}$ & 14.97 & A & 0.07 & 31.91 & 14.97 & $8.40)$ & 29 \\
\hline & M & 4.00 & B & 0.05 & 15.54 & 4.00 & $(3.76)$ & 24 \\
\hline \multirow{3}{*}{ ATC } & $\mathrm{C}$ & 13.22 & A & 3.21 & 25.18 & 13.22 & $6.38)$ & 32 \\
\hline & $\mathrm{T}$ & 14.19 & A & 2.24 & 37.06 & 14.19 & 7.60) & 30 \\
\hline & M & 8.09 & B & 0.46 & 21.54 & 8.09 & (6.15) & 25 \\
\hline \multirow{3}{*}{ ATB } & $\mathrm{C}$ & 12.57 & A & 2.92 & 33.49 & 12.57 & $5.88)$ & 31 \\
\hline & $\mathrm{T}$ & 15.45 & A & 2.03 & 36.31 & 15.45 & (9.72) & 31 \\
\hline & M & $5 \cdot 72$ & B & 0.23 & 24.08 & 5.72 & (5.33) & 28 \\
\hline
\end{tabular}

$\mathrm{C}=$ Control; $\mathrm{T}=$ Thermocycling; $\mathrm{M}=$ Mechanical loading; $\mathrm{Min}=$ Minimum; $\mathrm{Max}=$ Maximum;SD=Standar Deviation; and $\mathrm{N}=$ Beam number

Different letters represent a statistical difference between groups.

Table 3. Percentage (\%) of the distribution of fracture types for the specimens tested in each group

\begin{tabular}{|c|c|c|c|c|c|c|}
\hline $\begin{array}{l}\text { Restorative } \\
\text { System }\end{array}$ & Challenge & Adhesive & Mixed & $\begin{array}{c}\text { Cohesive } \\
\text { Resin }\end{array}$ & $\begin{array}{l}\text { Cohesive } \\
\text { Dentin }\end{array}$ & NF \\
\hline \multirow{3}{*}{ SFZ } & $\mathrm{C}$ & $37.9 \%(11) \mathrm{BC}$ & $41.4 \%(12) \mathrm{A}$ & $17.2 \%(5) \mathrm{A}$ & $3.4 \%(1) \mathrm{A}$ & 76 \\
\hline & $\mathrm{T}$ & $90.3 \%(28) \mathrm{A}$ & $0.0 \%(0) \mathrm{B}$ & $9.7 \%(3) \mathrm{A}$ & $0.0 \%(0) \mathrm{A}$ & 64 \\
\hline & M & $60 \%(12) \mathrm{B}$ & $10 \%(2) \mathrm{B}$ & $20 \%(4) \mathrm{A}$ & $10 \%$ (2) A & 96 \\
\hline \multirow{3}{*}{ SFB } & $\mathrm{C}$ & $24.1 \%(7) \mathrm{C}$ & $69.0 \%(20) \mathrm{C}$ & $6.9 \%(2) \mathrm{A}$ & $0.0 \%(0) \mathrm{A}$ & 61 \\
\hline & $\mathrm{T}$ & $86.2 \%(25) \mathrm{A}$ & $3.4 \%(1) \mathrm{B}$ & $10.3 \%(3) \mathrm{A}$ & $0.0 \%(0) \mathrm{A}$ & 81 \\
\hline & M & $91.7 \%(22) \mathrm{A}$ & $0.0 \%(0) \mathrm{B}$ & $8.3 \%$ (2) A & $0.0 \%(0) \mathrm{A}$ & 88 \\
\hline \multirow{3}{*}{ ATC } & $\mathrm{C}$ & $81.3 \%(26) \mathrm{AB}$ & $3.1 \%(1) \mathrm{B}$ & $15.6 \%(5) \mathrm{A}$ & $0.0 \%(0) \mathrm{A}$ & 38 \\
\hline & $\mathrm{T}$ & $76.7 \%(23) \mathrm{AB}$ & $10 \%(3) \mathrm{B}$ & $13 \cdot 3 \%$ (4) A & $0.0 \%(0) \mathrm{A}$ & 69 \\
\hline & M & $88 \%(22) \mathrm{A}$ & $0.0 \%(0) \mathrm{B}$ & $12 \%(3) \mathrm{A}$ & $0.0 \%(0) \mathrm{A}$ & 118 \\
\hline \multirow{3}{*}{ ATB } & C & $90.3 \%(28) \mathrm{A}$ & $3.2 \%$ (1) B & $6.5 \%(2) \mathrm{A}$ & $0.0 \%(0) \mathrm{A}$ & 60 \\
\hline & $\mathrm{T}$ & $80.6 \%(25) \mathrm{AB}$ & $6.5 \%$ (2) B & $12.9 \%(4) \mathrm{A}$ & $0.0 \%(0) \mathrm{A}$ & 60 \\
\hline & M & $85.7 \%(24) \mathrm{A}$ & $0.0 \%(0) \mathrm{B}$ & $7.1 \%(2) \mathrm{A}$ & $7.1 \%(2) \mathrm{A}$ & 96 \\
\hline
\end{tabular}
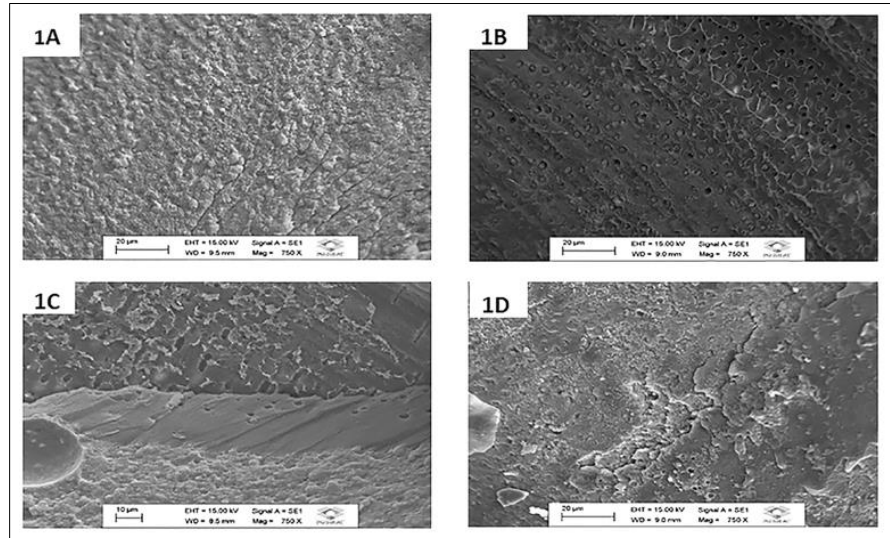

Figure 1: Scanning electronic microscopy analysis (750x). (A: Adhesive fracture of SFZ thermocycling subgroup; B: Adhesive fracture of SFB mechanical loading subgroup; C: Mixed-type fracture of SFZ control subgroup; D: Mixed type fracture image of SFB control subgroup).

DISCUSSION

Adhesion to dentin may present deficiencies, mainly related to adhesive degradation or gap formation at the dentin-composite interface ${ }^{14}$. These alterations can be harmful over time, causing low bond strength of the composite resin restorations ${ }^{15}$. Bond strength is an important method in assessing the stability of the bond between the substrate and tooth restoration, especially when using artificial aging techniques ${ }^{7}$. The $\mu$ TBS test allows the ability to obtain multiple bonding interfaces in the same specimen, providing a greater ability to predict the behavior of restorative systems ${ }^{8}$.

The thermocycling challenge produces thermal expansion and contraction between restorative materials and tooth, which may cause stresses at the interface, leading to gap formation and adhesive failure ${ }^{16}$. In this study, thermocycling did not promote statistical changes in bond strength for any restorative systems. This result indicates some important points. First, thermal contraction and expansion produced by conventional and bulk fill composite resins were similar, probably due to the composition of low-shrinkage composite resins, whose monomers are characterized by generating low shrinkage stress during polymerization, even when inserted in bulk up to a thickness of $4 \mathrm{~mm}^{4,16}$. Furthermore, the bulk fill and conventional composite resins in the current study contained BisGMA, UDMA, and Bis-EMA. Second, selective phosphoric acid enamel etching has been helpful in stabilizing and sealing the restorative composite adhesive interface, even after a prolonged period of thermal tensions ${ }^{3,16}$. Another study failed to find differences in $\mu$ TBS between incremental and bulkfill restorative systems (Filtek Z250 XT and Filtek bulk-fill, respectively) after thermocycling ${ }^{17}$. Costa et al. ${ }^{18}$ in a clinical trial compared the influence of composite resin insertion techniques (bulk-fill and incremental) and did not find a statistical difference between the restorative techniques in gap formation or marginal integrity.

In clinical conditions, restorations are constantly encountering stresses during mastication and parafunctional habits ${ }^{6}$. In this context, mechanical cycling was used to simulate occlusal force to restoration surface ${ }^{6,11}$. A statistical difference was observed between the conventional restorative system SFZ and bulk-fill composite resins SFB and ATB after mechanical loading, rejecting the first null-hypothesis. Furthermore, ATC, SFB and ATB had a statistically significant reduction in bond strength when submitted to mechanical loading when compared to the control and thermocycling conditions, rejecting the second null-hypothesis. Plastic deformation of the adhesive interface and concentration of main stresses in the hybrid layer interface could be a possible explanation for the present results, since masticatory loading could accelerate the degradation of the dentin bonding 
interface.6 Furthermore, fatigue could act on porosities and other internal defects within the adhesive or composite resin layer, with detrimental effects on the bonding durability ${ }^{6}$.

This result may also be related to the mechanical properties of the restorative material.16 Therefore, the modulus of elasticity and the reduction of mechanical properties can be considered more important than the contraction of materials when restorations are submitted to mechanical stress ${ }^{3,16}$. In this context, the low modulus of elasticity and the reduced amount of fillers of the bulk restorative materials likely influenced the behavior of the materials under mechanical stress ${ }^{16}$, even though these properties were considered suitable for the physical stress of thermocycling. SFB, ATC and ATB present less percentage of fillers by weight than SFZ, likely causing reduced mechanical properties, since SFZ presented statistically higher diametral tensile strength when compared to SFB and ATB ${ }^{19}$. Silame et al. $^{20}$ observed that 2-mm increment restorations in box-shaped cavities yielded higher $\mu$ TBS and microhardness for conventional and bulkfill composites when compared to 4-mm increments. When the teeth were restored with one bulk increment $(4 \mathrm{~mm})$, the deeper layers presented lower microhardness starting at $2 \mathrm{~mm}$ for a conventional microhybrid (Z250) and $3 \mathrm{~mm}$ for bulk-fill (Tetric EvoCeram) ${ }^{20}$ This observation may also explain the results obtained in the present study after mechanical loading.

When specimens were simultaneously thermocycled under thermodynamic conditions with a mechanical load of $49 \mathrm{~N}$ (600,000 cycles), no differences were found between conventional resin (Filtek Z350 XT) and bulk-fill resin (Tetric NCeram) when evaluating imperfect margin percentage using micro-CT images. The same observation was found in another study in which specimens were submitted to 240,000 mechanical cycles with occlusal loading of $49 \mathrm{~N}$ and 600 simultaneous thermal cycles $^{2}$. It is possible that the load of $49 \mathrm{~N}$ applied on specimens was not sufficient to influence the bond interface, since the present study utilized a load of 80 $\mathrm{N}^{21}$. A similar performance of the two types of resin composites (Tetric Ceram HB and Tetric N-Ceram Bulk Fill) was found when testing $\mu$ TBS in enamel and cementum after aging with only 5000 cycles of thermocycling and 1000 cycles of intermittent vertical occlusal loads between 25 and $100 \mathrm{~N}^{22}$. Previous studies reported that the force generated during routine mastication food is about 70 to $150 \mathrm{~N}$ 6 , with the vertical occlusal load in molars being between $20-140 \mathrm{~N}^{11}$. It is obvious that these challenges do not occur separately in the oral cavity, but that each one has a specific importance in the mechanisms of bond degradation ${ }^{23}$, as this present study showed. Since the constant and rapid assessment of adhesive materials in clinical trial studies is impossible, the use of thermocycling and mechanical loading to evaluate dental materials is required to simulate clinical conditions.

In the failure analysis, the control SFZ and SFB subgroups presented a higher percentage of mix failures (Figure 1C and 1D); however, the ATC and ATB groups reported a higher percentage of adhesive failures (Figure 1A and 1B). It is likely that the chemical bonding potential of the MDP monomer (10-Methacryloyloxydecyl dihydrogen phosphate) present in the Single Bond Universal ${ }^{19}$ may contribute to this higher percentage of mix failures. However, the thermo- and mechanical cycling promoted an improved percentage of adhesive failures for all groups. Plastic deformation of the adhesive interface during thermo- and mechanical cycling and the concentration of stress in the hybrid layer interface could be a possible explanation for the present results ${ }^{21,22}$. The majority of mixed failures were also obtained for other studies that evaluated debond strength of bulk fill composite resins ${ }^{17,22}$. Furthermore, the lowest values of bond strength were often correlated with adhesive failures ${ }^{17}$.

A limitation of this study was in obtaining beams, mainly after mechanical cycling, due to premature specimen failures. Thus, pretest failures were not included in the statistical analysis, since this failure can occur due to problems in sample processing ${ }^{8}$. It is important to emphasize that the $\mu$ TBS test evaluates the bond strength in a very small area; thus, a minimal defect in the adhesive interface may interfere with the retention of restorative material and induce early failures ${ }^{8}$. Although the cavity-type sample preparation may be recommended for $\mu$ TBS testing as a more clinically relevant strategy ${ }^{24}$, some clinical trials evaluating the performance of bulk restorative systems have shown good clinical effectiveness during a 3-year followup $^{25}$. Thus, more studies are needed to evaluate the long-term clinical performance of these restorative materials in order to provide more accurate results regarding retention rate.

CONCLUSION

In conclusion, the dentin bond strength of low-shrinkage composite resin restorations was negatively influenced by mechanical loading in class I cavities.

\section{REFERENCES}

1. Bedran-Russo A, Leme-Kraus AA, Vidal CMP, Teixeira EC. An overview of dental adhesive systems and the dynamic tooth-adhesive interface. Dent Clin N Am. 2017; 61:713-31.

2. Rosatto CM, Bicalho AA, Veríssimo C, Bragança GF, Rodrigues MP, Tantbirojn D, et al. Mechanical properties, shrinkage stress, cuspal strain and fracture resistance of molars restored 
with bulk-fill composites and incremental filling technique. J Dent. 2015;43:1519-28.

3. Ilie N, Bucuta S, Draenert M. Bulk-fill resinbased composites: an in vitro assessment of their mechanical performance. Oper Dent. 2013;38:18-25.

4. Caixeta RV, Guiraldo RD, Kaneshima EN, Barbosa AS, Picolotto CP, Lima AE, et al. Push-out bond strength of restorations with bulkfill, flow, and conventional resin composites. ScientificWorldJournal 2015; 2015:452976.

5. Amaral FL, Colucci V, Palma-Dibb RG, Corona SA. Assessment of in vitro methods used to promote adhesive interface degradation: a critical review. J Esthet Restor Dent. 2007;19:340-53.

6. Daneshkazemi A, Davari A, Akbari MJ, Davoudi A, Badrian H. Effects of thermal and mechanical load cycling on the dentin microtensile bond strength of Single Bond-2. J Int Oral Health 2015;7:9-13

7. Poptani B, Gohil KS, Ganjiwale J, Shukla M. Microtensile dentin bond strength of fifth with five seventh-generation dentin-bonding agents after thermocycling: An in vitro study. Contemp Clin Dent. 2012;3(Suppl 2):S167-71.

8. Heintze SD, Monreal D, Peschke A. Marginal quality of Class II composite restorations placed in bulk compared to an incremental technique: Evaluation with SEM and Stereomicroscope. J Adhes Dent. 2015;17:147-54.

9. Soares CJ, Pizi EC, Fonseca RB, Martins LR. Influence of root embedment material and periodontal ligament simulation on fracture resistance tests. Braz Oral Res. 2005;19:11-6.

10. Aguiar TR, André CB, Correr-Sobrinho L, Arrais CA, Ambrosano GM, Giannini M. Effect of storage times and mechanical load cycling on dentin bond strength of conventional and selfadhesive resin luting cements. J Prosthet Dent. 2014;111:404-10.

11. Assunção WG, Jorge JR, Dos Santos PH, Barão VA, Gomes EA, Delben JA. The effect of mechanical cycling and different misfit levels on Vicker's microhardness of retention screws for single implant-supported prostheses $\mathbf{J}$ Prosthodont. 2011;20:523-27.

12. De Munck J, Luehrs AK, Poitevin A, Van Ende A, Van Meerbeek B. Fracture toughness versus micro-tensile bond strength testing of adhesivedentin interfaces. Dent Mater. 2013;29:635-44.

13. Armstrong S, Breschi L, Özcan M, Pfefferkorn F, Ferrari M, Van Meerbeek B. Academy of Dental Materials guidance on in vitro testing of dental composite bonding effectiveness to dentin/enamel using micro-tensile bond strength ( $\mu$ TBS) approach. Dent Mater. 2017;33:133-43.

14. Tjäderhane L, Nascimento FD, Breschi L, Mazzoni A, Tersariol IL, Geraldeli $S$ et al. Strategies to prevent hydrolytic degradation of the hybrid layer- A review. Dent Mater. 2013; 29:999-11.

15. Taneja S, Kumar P, Kumar A. Comparative evaluation of the microtensile bond strength of bulk fill and low shrinkage composite for different depths of Class II cavities with the cervical margin in cementum: An in vitro study. J Conserv Dent. 2016;19:532-35.

16. Campos EA, Ardu S, Lefever D, Jassé FF, Bortolotto T, Krejci iI. Marginal adaptation of class II cavities restored with bulk-fill composites. J Dent. 2014;42;575-81.

17. Mandava J, Vegesna DP, Ravi R, Boddeda MR, Uppalapati LV, Ghazanfaruddin MD. Microtensile bond strength of bulk-fill restorative composites to dentin. J Clin Exp Dent. 2017;9:e1023-28.

18. Costa T, Rezende M, Sakamoto A, Bittencourt B, Dalzochio P, Loguercio AD, et al. Influence of adhesive type and placement technique on postoperative sensitivity in posterior composite restorations. Oper Dent. 2017;42:143-54.

19. Jayaseel A, Niranjan N, Pamidi H, Suryakanth MB. Comparative evaluation of shear bond strength of universal dental adhesives - An in vitro study. J Clin Exp Dent. 20171;9:e892-e96.

20. Silame FDJ, Geraldeli GP, Sinhoreti MAC, Piresde-Souza FCP, Roulet JF, Geraldeli S. Dentin $\mu$ TBS and hardness of bulk-fill and conventional composites placed in a box-shaped cavity preparation. J Adhes Dent. 2017;19:395-400.

21. Han SH, Park SH. Comparison of internal adaptation in class II bulk-fill composite restorations using micro-CT. Oper Dent. 2017;42:203-14.

22. Al-Harbi F, Kaisarly D, Michna A, ArRejaie
A, Bader
$\mathrm{D}$,
El Gezawi M.

Cervical interfacial bonding effectiveness of class

II bulk versus incremental fill resin composite restorations Oper Dent. 2015;40:622-35.

23. Amaral FL, Colucci V, Palma-Dibb RG, Corona SA. Assessment of in vitro methods used to promote adhesive interface degradation: a critical review J Esthet Restor Dent. 2007; 19:340-53.

24. Lezaja Zebic M, Dzeletovic B, Miletic V. Microtensile bond strength of universal adhesives to flat versus Class I cavity dentin with pulpal pressure simulation J Esthet Restor Dent. 2018;30:240-48.

25. Yazici AR, Antonson SA, Kutuk ZB, Ergin E. Thirty-six-month clinical comparison of bulk fill and nanofill composite restorations. Oper Dent. 2017;42:478-85. 


\section{CONFLICTS OF INTERESTS}

The authors declare no conflicts of interests.

\section{CORRESPONDING AUTHOR}

\section{Ticiane Cestari Fagundes}

Address: José Bonifácio, 1193,

City: Araçatuba, Postcode: 16015-050,

Country: Brazil

Phone number: $(+55) 183636-3347$

E-mail: ticiane.fagundes@unesp.br

Received 18/01/2020

Accepted 09/07/2020 